\title{
ISOLATION OF ENDOPHYTIC FUNGI FROM THE COASTAL PLANT TERONG PUNGO (Solanum sp.) AND ITS ANTIBACTERIAL ACTIVITY AGAINST ORAL PATHOGENIC BACTERIA**
}

\author{
NABILA UKHTY ${ }^{1,2}$, KUSTIARIYAH TARMAN $^{1,3 *}$, and IRIANI SETYANINGSIH ${ }^{1}$ \\ 'Department of Aquatic Products Technology, Faculty of Fisheries and Marine Sciences, \\ Institut Pertanian Bogor, Bogor 16680, Indonesia \\ ${ }^{2}$ Department of Fisheries, Faculty of Fisheries and Marine Science, \\ Universitas Teuku Umar, Meulaboh, Aceh 23681, Indonesia \\ ${ }^{3}$ Marine Biotechnology Division, Center for Coastal and Marine Resources Studies, \\ Institut Pertanian Bogor, Bogor 16680, Indonesia
}

Received 8 January 2015/Accepted 8 August 2016

\begin{abstract}
Coastal plant locally known as terong pungo (Solanum sp.) was used by Aceh community as traditional medicine for toothache. The objectives of this study were to isolate endophytic fungi from the leaves of terong pungo and determine the antibacterial activity of the fungi against bacteria causing dental caries and infection. Eight endophytic fungi were isolated. Antagonism test among the isolates was performed to select the most dominant fungus. TP6 was the selected fungus based on the antagonism assay. Crude extracts of the fungus were macerated from the culture broth using ethyl acetate. The strongest antibacterial activity of the extracts was obtained when the fungus was at 12 days of cultivation. The fungal crude extract was strongly active against Staphylococcus aureus, Staphylococcus epidermidis and Pseudomonas aeruginosa with inhibition zone diameter of 20,21 and $23 \mathrm{~mm}$, respectively.
\end{abstract}

Keywords: Endophytes, medicinal plant, toothache, traditional medicine

\section{INTRODUCTION}

In the oral cavity, bacteria are often associated with the oral and dental diseases. Caries and periodontal diseases seem to appear following an imbalance in the oral resident microbiota, leading to the emergence of potentially pathogenic bacteria (Marcote \& Lavoie 1998). Streptococcus mutans, Pseudomonas aeruginosa, Staphylococcus aureus and Staphylococcus epidermidis often times can be isolated from the mouth of a patient. These bacteria are known as normal bacteria in the mouth, however, they might become pathogenic because of predisposing

* Corresponding author: kustya@gmail.com

** This paper was presented at International Conference on Integrated Coastal Management and Marine Biotechnology, Emphasizing on ICM Practices and Applications. 29 - 30 November 2016. Bogor, Indonesia. factors such as changes in the quantity of bacteria and decreasing immune system, which cause dental caries and infection (Al-Bayati \& Sulaiman 2007).

There are several health products available commercially as anti-microbiota for oral cavity and dental, but the products mostly contain alcohol as antibacterial, which may cause side effect such as vomit, diarrhea and stained teeth (More et al. 2008). The carcinogenic properties of alcohol may happen when there is formation of acetaldehyde in the oral cavity (Bean et al. 2007; McCullough \& Farah 2008; Lachenmeier et al. 2009). These side effects of alcohol trigger efforts in finding safer and more effective active compounds in oral health products.

Terong pungo (Solanum sp.) (Fig. 1) is a coastal plant, usually used by Aceh community to treat toothache. 


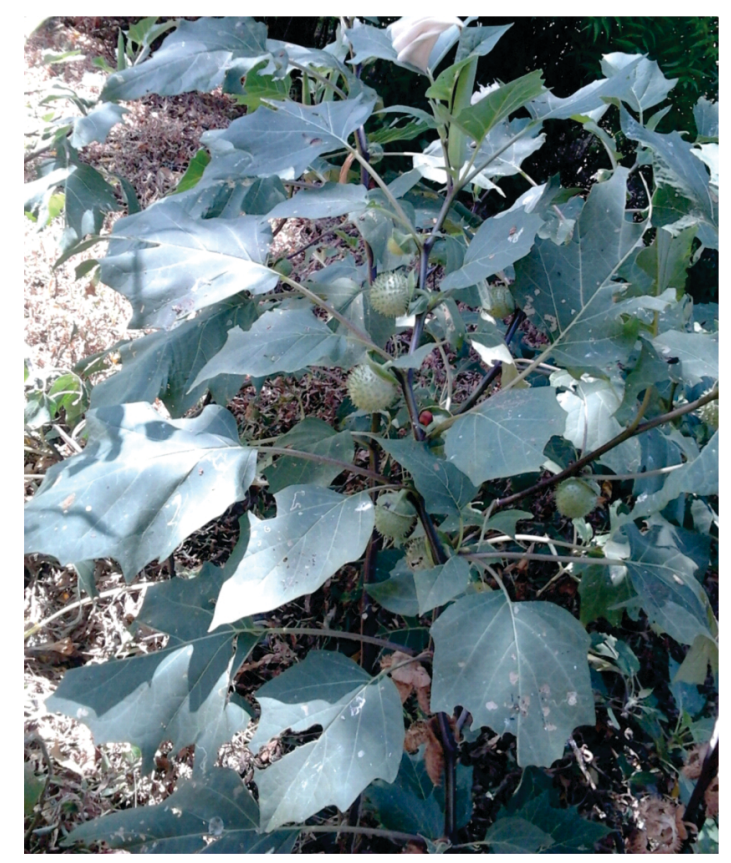

Figure 1 Terong pungo (Solanum sp.) showing leaves and fruit

The ethyl acetate crude extract of terong pungo leaf showed antibacterial activity against Escherichia coli and Staphylococcus aureus (Hardjito 2008). The ethanol extracts of Solanum surattense showed the antibacterial activity against Staphylococcus aureus, Bacillus subtilis, Escherichia coli, Pseudomonas aeruginosa, Salmonella typhi, Shigella dysenteriae and Vibrio cholerae (Sheeba 2010).

Endophytic fungi associated with terong pungo plant produce active compounds which are similar to the compounds produced by its host. Strobel et al. (2004) stated that the endophytic fungi can be isolated from seed, leaf, flower, branch, stem and root of the host plant. Jena and Tayung (2013) reported that several endophytic fungi isolated from Solanum ubrum could produce secondary metabolites as source of antimicrobial and antifungal compounds. This study was aimed at isolating endophytic fungi from terong pungo leaf and observing the potential of the fungal bioactive compounds as antibacterial for oral pathogenic bacteria.

\section{MATERIALS AND METHODS}

\section{Collection of Sample}

The leaves of terong pungo (Solanum sp.) was collected from the coastal area of Pidie District, Aceh Province, Indonesia. Mature healthy plant leaves were collected from different parts of the trees. Leaf samples from each plant were randomly cut off and placed separately in sterile plastic bags and stored in low temperature $\left(4.5^{\circ} \mathrm{C}\right)$ for two days until being used for endophytic fungi isolation.

\section{Isolation of Endophytic Fungi}

The Solanum leaves were sterilized using 70\% alcohol for 2 minutes and then rinsed with sterile water for 1 minute. The sterilized leaves were cut into $1 \mathrm{x} 1 \mathrm{~cm}$ pieces and then put the leaf pieces in petri dish containing Potato Dextrose Agar (PDA), four pieces for each petri dish. Petri dishes containing pieces of Solanum leaves were then incubated at room temperature $\left(27-29{ }^{\circ} \mathrm{C}\right)$ for 12 - 14 days. These pieces of leaves were checked once a day to observe the growth of hyphal tips of the endophytic fungi. The growing hyphal tips were immediately transferred into other petri dishes containing fresh PDA and kept incubated at $27-29{ }^{\circ} \mathrm{C}$ to get pure isolate (Arnold et al. 2003). Isolation process was conducted in a clean bench (Thermo Scientific 1300 Series A2).

\section{Antagonism Test of Endophytic Fungi}

The antagonism assay was performed by inoculating $2-3$ isolates of potential endophytic fungi on PDA medium. The inoculum was a $5 \mathrm{~mm}$ piece of isolate on PDA medium. The 
inoculum was incubated at $27-29{ }^{\circ} \mathrm{C}$ (room temperature) (Sudantha \& Abadi 2007). The purpose of this test was to determine which isolates grow dominantly.

\section{Characterization of Endophytic Fungi}

The 7 days old endophytic fungi were characterized based on macroscopic and microscopic morphology. The macroscopic observation included the fungal shape, surface, color and edge form. The microscopic properties were observed using microscope (Cole Parmer) with 400x magnification. Fungal isolates were identified based on their morphological characters, such as conidiospore structures using standard identification manuals (Barnett \& Hunter 1972; Gandjar et al.2000).

\section{Cultivation of Endophytic Fungi}

The selected endophytic fungi were mass cultivated on Potato Dextrose Broth (PDB) by placing agar blocks of actively growing pure culture ( $3 \mathrm{~mm}$ in diameter) in $250 \mathrm{~mL}$ Erlenmeyer flask at $28^{\circ} \mathrm{C}$, which was then mixed using orbital shaker at $150 \mathrm{rpm}$ (Srikandace et al. 2007). Harvesting was conducted by filtering the mycelia using sterile filter paper to separate the mycelia from the culture medium. Mycelia were then dried and measured as the biomass of endophytes. The culture medium was used for extraction of bioactive compounds. Fungal growth and $\mathrm{pH}$ of the culture were observed every 3 days for 21 days.

\section{Extraction of Bioactive Compounds}

Culture medium of the harvested fungi was macerated using ethyl acetate for $3 \times 24$ hours by shaking the medium at $150 \mathrm{rpm}$ (Tarman 2011). The results of the extraction were separated using a separating funnel, then concentrated using a rotary vacuum evaporator (Heidolph VV 2000) at $45^{\circ} \mathrm{C}$ to produce the crude extracts. The crude extracts were used for antibacterial bioassay.

\section{Antibacterial Activity against Oral Bacterial Pathogens}

Antibacterial assay was performed in vitro against Streptococcus mutans, Pseudomonas aeruginosa, Staphylococcus aureus and Staphylococcus epidermidis. All bacterial cultures were obtained from the
Culture Collection of the Laboratory of Microbiology, Universitas Indonesia. This assay was performed using agar well diffusion technique, which was modified from Holo et al. (1991).

The antibacterial assay used two bacteria (S. mutans and $P$. aeruginosa) to test the periodic for obtaining the optimum time of fungal culture. The fungus was then cultured based on this result.

Streptococcus mutans was grown on Blood Agar (BA), while $P$. aeruginosa, $S$. aureus and $S$. epidermidis were grown on Nutrient Agar (NA). Those bacteria were then incubated at $37^{\circ} \mathrm{C}$ for 24 hours. Furthermore, $S$. mutans was suspended in Brain Heart Infusion (BHI), while P. aeruginosa, S. aureus and $S$. epidermidis were suspended in Nutrient Broth (NB). These bacteria were then incubated at $37^{\circ} \mathrm{C}$ for 24 hours.

Optical density (OD) was measured using a UV Vis spectrophotometer (UV-2500). The optical density (OD) used was approximately 0.5. An amount of $20 \mu \mathrm{L}$ bacteria was inoculated on MHA+sterile sheep blood for $S$. mutans and on MHA for $P$. aeruginosa, $S$. aureus and $S$. epidermidis. MHA medium containing test bacteria were then prepared with 8 wells for positive and negative controls and 3 extracts with different concentrations $(0.5,1$ and $2 \mathrm{mg} /$ well $)$. All concentrations and controls were performed in two replications. The positive controls used were amoxicillin and chloramphenicol with concentration of $300 \mu \mathrm{g} /$ well. The negative control was ethyl acetate as the solvent for extraction process. The incubation was performed at $37{ }^{\circ} \mathrm{C}$ for 24 hours. Inhibition zone appeared around the well was measured. The data were analyzed descriptively into the bar chart.

\section{RESULTS AND DISCUSSION}

\section{Endophytic Fungi Isolated from Terong Pungo (Solanum sp.)}

Eight isolates obtained from the endophytic fungi were TP1, TP2, TP3, TP4, TP5, TP6, TP7 and TP8. Guo et al. (2000) stated that the grouping of fungal isolates can be based on morphospecies i.e. based on the similarity of color and surface texture of the colony, pigmented hyphae, exudates, edge shape, growth rate and sporulation 
structures. Based on the morphospecies, the endophytic fungi obtained from the leaf of terong pungo were identified as Aspergillus spp., Trichoderma spp. and Fusarium spp.

\section{Selection Result of Endophytic Fungi}

Antagonism assay was conducted to determine which isolates grow dominantly (Fig. 2). In this research, the antagonism assay was performed by direct opposition method, i.e. three fungal isolates co-cultured in the same plate. Based on the antagonism test, TP6 isolate was the most dominant among other isolates. It is generally assumed that the dominancy of an organism related to the production of secondary metabolites which are important as chemical defense. Therefore, TP6 isolate was selected for further research step.

\section{Characteristics of Isolate TP6}

Macroscopic and microscopic characteristics of the selected fungal TP6 isolate are presented in Figure 3. Figure 4 presents the fungal growth for 21 days.

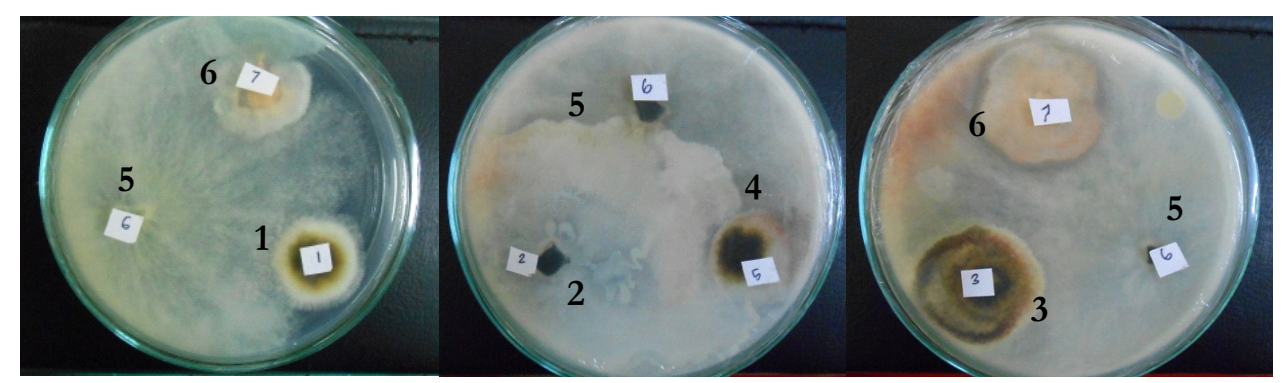

Figure 2 Antagonism test among endophytic fungi of Solanum sp. (Notes: Isolate numbers: $1=\mathrm{TP} 1 ; 2=\mathrm{TP} 2 ; 3=\mathrm{TP} 3 ; 4=\mathrm{TP} 5 ; 5=\mathrm{TP} 6 ; 6=\mathrm{TP} 7$ )

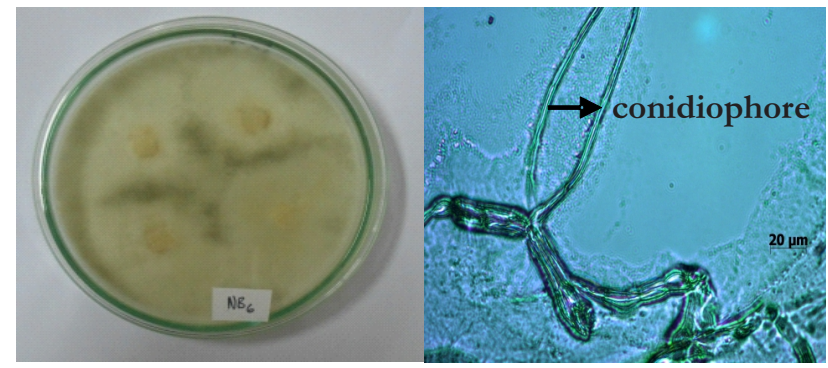

A
$\mathrm{B}$

Figure 3 TP6 isolate on PDA medium (A) and 400x magnification (B)

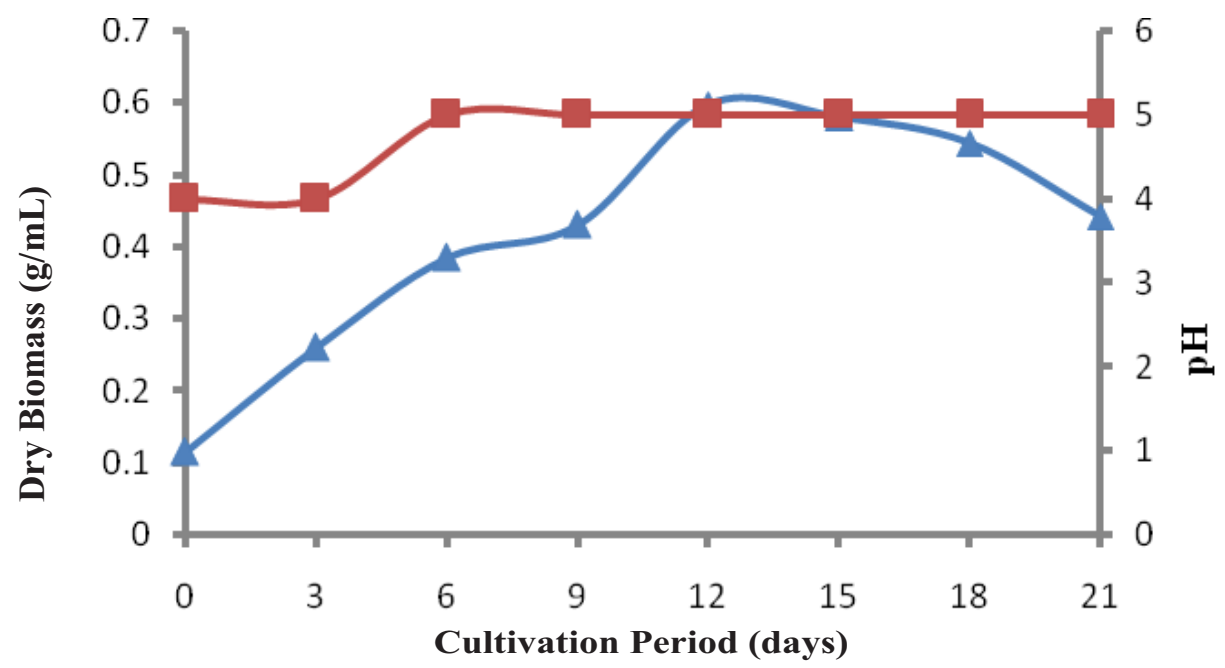

Figure 4 Growth curve of TP6 isolate during 21 days

(Notes: $\Delta=$ Dry biomass, $\square=\mathrm{pH}$ ) 
The macroscopic characteristics of TP6 isolate were grey mycelia, uneven surface with abundant hypha growing at the colony edge and greyish green as the reverse color. The microscopic observation at 400x magnification showed that the fungus has long conidiophores. However, the TP6 isolate has not been identified into the genus or species.

The TP6 isolate was then cultured on Potato Dextrose Broth (PDB) for 21 days at room temperature with orbital shaking at $120 \mathrm{rpm}$. The fungus growth was determined using dry weight of the mycelia which were harvested every 3 days for 21 days cultivation. According to Meletiadis et al. (2001) fungal growth has 4 phases consisting of lag, log, stationary and death phases. TP6 fungus was in logarithmic phase until day 12; the stationary phase was reached on day 12 until day 18; and finally on day 18 TP6 started to reach death phase. Growth phase is closely related to the fungal nutrient sufficiency in their media (Srikandace et al. 2007). According to Kusumaningtyas et al. (2010) the PDB medium contains potato dextrose as carbon source which is the crucial component for microbial growth. The primary substances of the microbe cells are carbon and nitrogen. Therefore, if the carbon is unavailable, the growth will be disrupted. Lack of carbon also causes cell death.

\section{Antibacterial Activity against Oral Bacteria}

The test organisms in this study were Streptococcus mutans, Pseudomonas aeruginosa,
Staphylococcus epidermidis and Staphylococcus aureus. Streptococcus mutans attaches to the tooth surface by producing glucuronyl transferase enzyme which causes plaque and colonies on the surface of the tooth (Shulman et al. 1992). Pseudomonas aeruginosa can be found in the oral cavity (Komiyama et al. 1985) and is an opportunistic bacterium that can cause severe infection in susceptible patients (Iversen et al. 2007). Staphylococcus epidermidis and Staphylococcus aureus are normal flora bacteria which can produce toxin when their normal habitats are disturbed (Torabinejad \& Walton 2009). These bacteria cause toothache.

Antibacterial activity of the crude extract of TP6 fungus was observed every 3 days for 21 days cultivation (day 3, 6, 9, 12, 15, 18 and 21) to determine the optimum fungal growth which produced the highest antibacterial activity. The antibacterial activity of the fungal crude extracts against $P$. aeruginosa and $S$. mutans is shown in Figure 5.

Crude extract of endophytic TP6 fungus showed antibacterial activity against $P$. aeruginosa. However, it was not active against $S$. mutans because the inhibition zone was not detected. Fungal crude extract obtained from culture broth harvested at day 12 showed the highest antibacterial activity against $P$. aeruginosa with inhibition zone diameter of $22.5 \mathrm{~mm}$ for $2 \mathrm{mg}$ extract/well; $20 \mathrm{~mm}$ diameter for $1 \mathrm{mg}$ extract/well; and $15.5 \mathrm{~mm}$ diameter for $0.5 \mathrm{mg}$ extract/well. Based on this result, the TP6 fungus was cultured for 12 days.

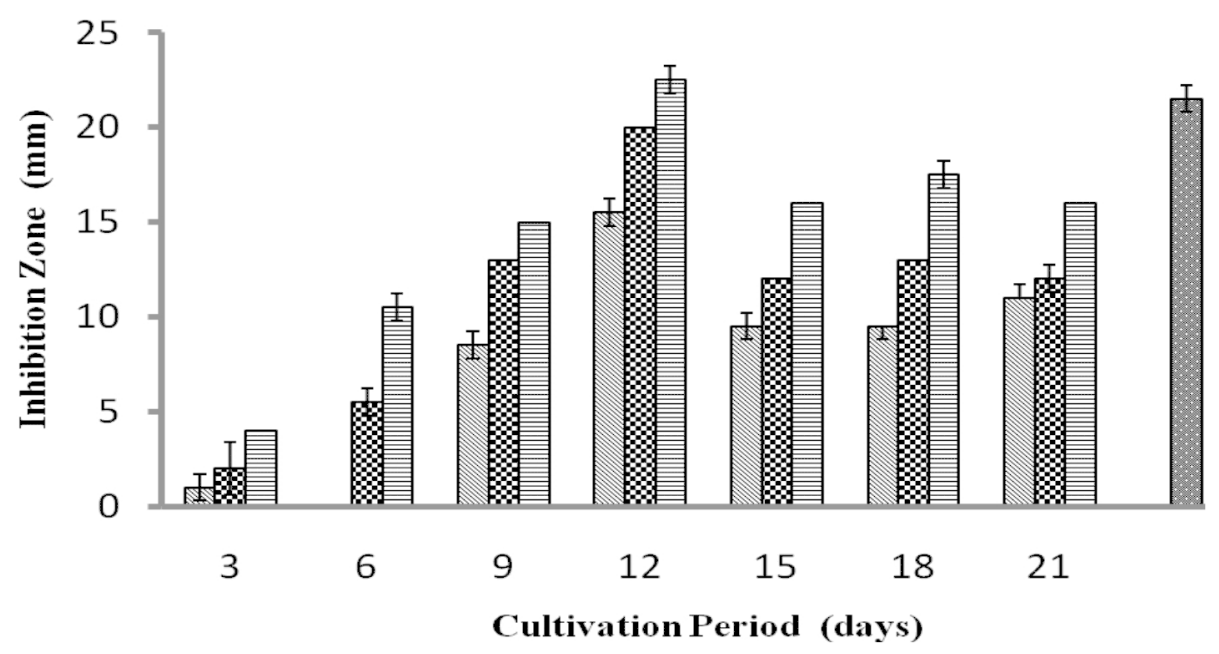

Figure 5 Antibacterial activity against Pseudomonas aeruginosa using ethyl acetate crude extract of TP6 isolate $(\mathbb{\mathbb { N }}=0.5 \mathrm{mg}$ concentration, $\mathbb{Q}=1 \mathrm{mg}$ concentration, 苞= $2 \mathrm{mg}$ concentration and $\square=$ positive control) (Note: The data presented are mean \pm SD of 2 replications) 


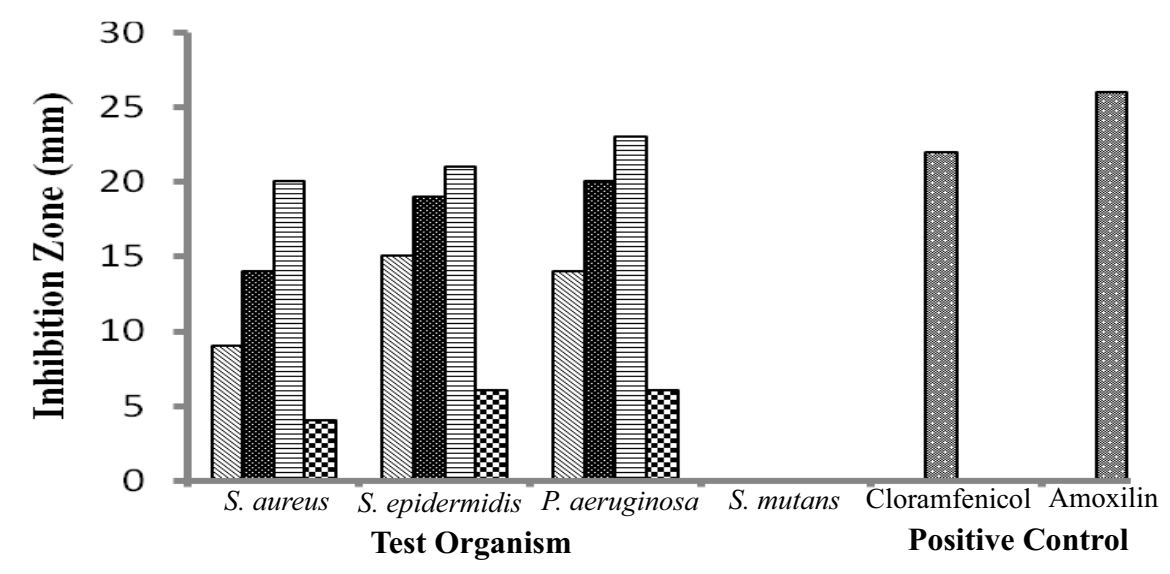

Figure 6 Antibacterial activity of ethyl acetate crude extract of TP6 isolate against oral pathogenic $(\mathbb{\mathbb { N }}=$ TP6 $0.5 \mathrm{mg}$,

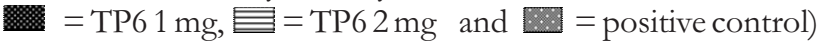

(Note: The data presented are mean \pm SD of 2 replications)

Secondary metabolites are commonly produced in stationary phase. Secondary metabolites are not essential for the cultures growth, but serve survival functions in nature and are usually produced during the late growth phase (Demain \& Fang 2000). Simanjuntak et al. (2002) stated that secondary metabolites are produced by fungus with the highest intensity at the end of exponential phase or at the beginning of stationary phase. Therefore, in this study, the antibacterial activity of the extracts harvested more than day 12 was decreasing.

The crude extract was not active against $S$. mutans which may have been caused by the developing resistance of the bacterium. According to Millar et al. (2001) bacterial resistance against antibacterial compound is formed by three mechanisms, such as insufficient drugs, inactive drugs and physiological change of bacteria.

Further antibacterial assay against $S$. mutans, $S$. aureus, $S$. epidermidis and $P$. aeruginosa was performed for the fungal crude extracts which were cultured for 12 days. The antibacterial activity of the crude extracts against all test bacteria is presented in Figure 6.

The crude extracts showed antibacterial activity against Staphylococcus aureus, Staphylococcus epidermidis and Pseudomonas aeruginosa with inhibition zone diameter of 20, 21 and $23 \mathrm{~mm}$ for $2 \mathrm{mg}$ extract/well, respectively. This antibacterial activity was as strong as the inhibitory ability of the positive control used i.e. chloramphenicol, with inhibition zone diameter of $22 \mathrm{~mm}$ for
$300 \mu \mathrm{g}$ per well. Whereas the amoxicillin as the positive control for antibacterial activity against S. mutans was stronger as the inhibitory ability than the crude extracts with inhibition zone diameter $25 \mathrm{~mm}$ for $300 \mu \mathrm{g}$ per well.

Antibacterial assay showed that crude extracts possessed a broad spectrum of antibacterial activity since the extracts inhibited the growth of Gram-positive and Gram-negative bacteria. In this study, $S$. aureus and $S$. epidermidis represented Gram-positive bacteria, while $P$. aeruginosa represented Gram-negative bacteria. However, the extracts were not active against $S$. mutans. This may have been caused by the resistance properties developed in S. mutans.

\section{CONCLUSIONS}

Eight isolates of endophytic fungi having different morphology were collected i.e. TP1, TP2, TP3. TP4, TP5, TP6, TP7 and TP8. Fungal isolate TP6 showed antibacterial activity against oral pathogenic bacteria such as Staphylococcus aureus, Staphylococcus epidermidis and Pseudomonas aeruginosa. The optimum activity was exhibited when the fungus was cultivated for 12 days.

\section{REFERENCES}

Al-Bayati FA, Sulaiman KD. 2007. In vitro antimicrobial activity of Salvadora persica L. extracts against some isolated oral pathogens in Iraq. Turkish J Biol 32:5762. 
Arnold AE, Mejia LC, Kyllo D, Rojas EI, Maynard Z, Robbins N, Herre EA. 2003. Fungal endophytes limit pathogen damage in a tropical tree. PNAS, 100(26): 15649-54.

Barnett HL, Hunter HH. 1972. Illustrated genera of imperfect fungi. Minneapolis (US): Burgers Company. 218 p.

Bean R, Straif K, Grosse Y, Secretan B, El Ghissassi F, Bouvard V. 2007. Carcinogenicity of alcoholic beverages. J Lancet Oncol 8:292-3.

Demain AL, Fang A. 2000. The natural functions of secondary metabolites. In: Advances in biochemical engineering biotechnology. Vol. 69. Scheper T, editor. Berlin (DE): Springer-Verlag. p. 20-9.

Gandjar I, Samson RA, Vermeulen, Oetari A, Santoso I. 2000. Pengenalan kapang tropik umum. Jakarta (ID): Yayasan Obor Indonesia. p. 33-40.

Guo LD, Hyde KD, Liew ECY. 2000. Identification of endophytic fungi from Livistona chinensis based on morphology and rDNA sequences. J New Phytol 147:617-30.

Hardjito L. 2008. Antibacterial and topoisomerase-I inhibitor activities of the coastal ethnomedicinal plant terong pungo (Solanum sp.). J Microbiol Indones 2(2).

Holo H, Nilssen, Ness IF. 1991. Lactococcin A: a new bacteriocin from Lactococcus lactis subsp. cremoris: isolation and characterization of the protein and its gene. J Bacteriol 38:79-87.

Iversen BG, Jacobsen T, Eriksen HM, Bukholm G, Melby KK, Nygård K, Aavitsland P. 2007. An outbreak of Pseudomonas aeruginosa infection caused by contaminated mouth swabs. Clin Infect Dis 44:794801.

Jena SK, Tayung K. 2013. Endophytic fungal communities associated with two ethno-medicinal plants of Similipal Biosphere Reserve, India and their antimicrobial prospective. JAPS 3(4):S7-S12.

Komiyama K, Tynan JJ, Habbick BF, Duncan DE, Liepert DJ. 1985. Pseudomonas aeruginosa in the oral cavity and sputum of patients with cystic fibrosis. Oral Surg Oral Med Oral Pathol 59(6):590-4.

Kusumaningtyas E, Natasia M, Darmono. 2010. Potensi metabolit kapang endofit rimpang lengkuas merah dalam menghambat pertumbuhan Escherichia coli dan Staphylococcus aureus dengan media fermentasi PDB dan PDY. Prosiding Seminar Nasional Teknologi Peternakan dan Veteriner. 20 Mei 2010. Bogor, Indonesia. p. 819-24.

Lachenmeier DW, Gumbel-Mako S, Sohnius EM, KeckWilhelm A, Kratz E, Mildau G. 2009. Salivary acetaldehyde increase due to alcohol containing mouthwash use: a risk factor for oral cancer. Int. J Can 125:730-5.

Marcote H, Lavoie MC. 1998. Oral microbial ecology and the role of salivary immunoglobulin A. Microbiol Mol Biol Rev 62(1):71-109.

McCullough MJ, Farah CS. 2008. The role of alcohol in oral carsinogenesis with particular reference to alcohol-containing mouthwashes. Aust Dent J 53:302-5.

Meletiadis J, Meis FGM, Mouton JW, Vermeij PE. 2001. Analysis of growth characteristics of filamentous fungi in different nutrient media. J Clin Microbiol, 39(2): 478-84.

Millar MR, Walsh TR, Linton CJ. 2001. Carriage of antibiotic-resistant bacteria by healthy children. J Antimicrob Chemother 47:605-10.

More G, Tshikalange TE, Lall N, Botha F, Meyer JJM. 2008. Antimicrobial activity of medicinal plants against oral microorganism. J Ethnopharmacol 119(3):4737.

Sheeba E. 2010. Antibacterial activity of Solanum surattense Burm. F. J Sci.Eng. Tech Kathmandu University 6(1):1-4.

Shulman ST, Phair JP, Somers HM. 1992. The biological and clinical basis of infectious disease. Fifth Edition. Philadelphia (US): WB.Saunders Company. p. 110-6.

Simanjuntak P, Melliawati R, Soekmanto A, Parwati T, Bustanussalam. 2002. Pengembangan bahan baku zat bioaktif anti malaria dari kapang endofit tumbuhan obat Indonesia. Laporan Teknik Penelitian Puslit Biotek-LIPI, Cibinong, Bogor 8(1): 49-54.

Srikandace Y, Hapsari Y, Simanjuntak P. 2007. Seleksi mikroba endofit Curcuma zedoaria dalam memproduksi senyawa kimia antimikroba. JIFI $5(2): 77-84$

Strobel G, Daisy, Castillo, Harper J. 2004. Natural product from endophytic microorganism. J Nat Prod 67:257-68.

Sudantha IM, Abadi AL. 2007. Identifikasi kapang endofit dan mekanisme antagonismenya terhadap kapang Fusarium oxysporum f.sp. vanillae pada tumbuhan vanili. Jurnal Agroteksos 17(1):23-38.

Tarman K. 2011. Biological and chemical investigations of Indonesian marine-derived fungi and their secondary metabolites. Göttingen (DE): Cuvillier Verlag. p. 32-5.

Torabinejad M, Walton RE. 2009. Principles and practice of endodontic. Fourth Edition. Philadelphia (US): Sounders Company. p. 58-63. 